\title{
Extracellular Enzymes of Microorganisms
}




\section{Extracellular \\ Enzymes of Microorganisms}

Edited by

J. Chaloupka

and

V. Krumphanzl

Institute of Mic robiology

Czecboslovak Academy of Sciences

Prague, Czechoslovakia

Plenum Press $\bullet$ New York and London 


\section{Library of Congress Cataloging in Publication Data}

Extracellular enzymes of microorganisms.

Includes bibliographical references and index.

1. Extracellular enzymes-Congresses. I. Chaloupka, Jirí. II. Krumphanzl, V. (Válcav) QR90.E98 1987

$576^{\prime} .11925$

87-14102

ISBN-13: 978-1-4684-1276-5 e-ISBN-13: 978-1-4684-1274-1

DOI: $10.1007 / 978-1-4684-1274-1$

Proceeding of an international symposium on Extracellular Enzymes of Microorganisms, held September 1-5, 1986, at Bechyne Castle, Czechoslovakia

(C) 1987 Plenum Press, New York

Softcover reprint of the hardcover 1st edition 1987

A Division of Plenum Publishing Corporation

233 Spring Street, New York, N.Y. 10013

All rights reserved

No part of this book may be reproduced, stored in a retrieval system, or transmitted in any form or by any means, electronic, mechanical, photocopying, microfilming, recording, or otherwise, without written permission from the Publisher 
Czechoslovak Society for Microbiology and Institute of Microbiology of the Czechoslovak Academy of Sciences organized an international symposium "Extracellular enzymes of microorganisms" in September 1986. The symposium took place in a small South-Bohemian town Bechyne and this book includes the main contributions presented at the meeting.

The study of microbial extracellular enzymes is a rapidly developing field of science, which is important both from practical and theoretical point of view. On one hand, microbial enzymes are nowadays broadly used in various branches of industry, medicine and agriculture, on the other hand, their study contributes substantially to our knowledge of problems of protein secretion, regulation of protein synthesis as related with growth and cytodifferentiation and - last but not least - it brings data important for the elucidation of evolutionary pathways. Microbial enzymology also represents a bordering area between different scientific disciplines such as microbiology, biochemistry, genetics, biotechnology and other and demonstrates that only their integration brings about a substantial progress in the development of our understanding of biological processes.

The symposium in Bechynè was a small one but the contributions of scientists from 15 different countries have brought information on recent approaches and developments in this field. I hope that this meeting was useful in facilitating closer contacts between specialists from different scientific areas and also contributed to a better understanding among people from different parts of the world.

Prof. Vladimir Krumphanzl

Corresponding Member of the Czechoslovak Academy of Sciences, Director of the Institute of Microbiology and President of the Czechoslovak Soclety for Microbiology 
CONTENTS

PART I

GENERAL ASPECTS OF ENZYME FORMATION

Regulation of Extracellular Enzyme Synthesis

F.G. Priest

A Comparison of the Characteristics of Extracellular Protein Secretion by a Gram-positive and Gramnegative Bacterium

G. Coleman, B. Abbas Ali, J. Sutherland, F. Fyfe, and A. Finley

Modelling of Physiological Control of Production of Hydrolytic Enzymes

J. Votruba, J. Pazlarová, and J. Chaloupka

Cloning, Sequencing, and Expression in E. coli and

B. subtilis of a Staphylokinase Gene

D. Behnke, D. Gerlach, and R. Kraft

Effect of Cerulenin on Bacillus subtilis 168

S. Baykousheva, N. Cherepova, and K. Illeva

Production of Extracellular Enzymes by Immobilized Microorganisms

H. Ruttloff, D. Körner, and A. Leuchtenberger

New Gene-transfer Systems for Aspergillus niger

I. Mattern, W. van Hartingsveldt, C. van Zeij1, P. Punt, R. Oliver, M. Dingemanse, P. Pouwels, and $C$. van den Hondel

Structure of Thermitase, a Thermostable Serine Proteinase from Thermoactinomyces vulgaris, and Its Relationship with Subtilisin-type Proteinases

M. Baudys, B. Meloun, V. Kostka, G. Hausdord, C. Frömme1, and W.E. Höhne

Regulation of Synthesis of an Extracellular Proteinase in Growing and Sporulating Bacillus megaterium

J. Chaloupka, H. Kucerová, M. Strnadová, L. Váchová, M. Dvoráková, J. Pazlarová, J. Moravcová, J. Votruba, and $\mathrm{K}$. Vanatalu 
Stimulation of a Proteinase Synthesis in Bacillus megaterium by Netropsin

H. Kucerová and J. Chaloupka

Extracellular Protease Production by $B$. amyloliquefaciens

M.J. Bawden, T. Litjens, T.R. Hercus, B.K. May, and W.H. Elliott

Formation and Properties of a Bacillus subtilis Protein Protease Inhibitor

A.I. Aronson

Use of Highly Porous Bead Cellulose with Attached Bacitracin for Affinity Chromatography of a Microbial Proteinase

J. Turková, M.J. Benes, M. Kühn, V.M. Stepanov, and L.A. Lyublinskaya

Saccharomyces Cerevisiae Secretes X-proly1-dipeptidy1(amino)peptidase. Electron Cytochemical Study with Statistical Evaluation

$\mathrm{J}$. Vorlsek and $\mathrm{K}$. Vanatalu

Production of $\alpha$-amylase by Bacillus stearothermophilus (pAT9) and Gene Manipulation to Improve the Stability of the Recombinant Plasmid

S. Aiba, Y. Monden, M. Ohnishi, M. Zhang, and J. Koizumi

Thermostable Alpha Amylase of Bacillus stearothermophilus:

Cloning, Expression and Secretion by Escherichia coli

I. Suominen, M. Karp, J. Lautamo, J. Knowles, and P. Mäntsälä

Exocellular Protein and $\alpha$-amylase Secretion in Bacillus substilis

J. Pazlarová

Extracellular Amylase from the Thermophilic Fungus Thermomyces lanuginosus

B. Jensen, J. 01sen, and K. Allermann

PART IV

CELLULOLYTIC ENZYMES

Analysis of Multi-form Cellulases of Sporotrichem cellulophilum

S. Kinoshita, M. Tamaki, J. Kim, A. Svarachorn, A. Araujo, and $\mathrm{H}$. Taguchi

Cellulase Secretion from a Hypercellulolytic Mutant of Trichoderma reese1 RUT-C30

B.K. Ghosh, A. Ghosh, and A. Salnar

Production of $\beta$-glucosidase in Aspergillus terreus ATG-5

0. Volfová and E. Kysliková 


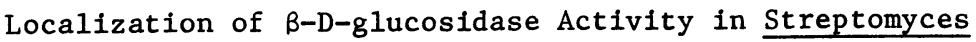
granaticolor ETH 7347

M. Jiresová, Z. Dobrová, J. Janecek, and J. Náprstek

Differentiation of Glycanases of Microbial Cellulolytic Systems using Chromogenic and Fluorogenic Substrates

P. Biely

PART V

OTHER ENZYMES

Biosynthesis and Properties of Extracellular Pullulanase from Bacillus stearothermophilus G-82

M.S. Kambourova and E.I. Emanuilova

Continuous Production of the Extracellular Hydrolytic System by Immobilized Mycelia of Alternaria tenuissima

V. Jirků

Export of Enzymes into Culture Medium by Yeasts of Saccharomyces genus

A.B. Tslomenko, V.V. Lupashin, and I.S. Kulaev 